\title{
Vitamin K2 and cotylenin A synergistically induce monocytic differentiation and growth arrest along with the suppression of $c-M Y C$ expression and induction of cyclin G2 expression in human leukemia HL-60 cells
}

\author{
YASUHISA MANIWA $^{1}$, TAKASHI KASUKABE ${ }^{2}$ and SHUNICHI KUMAKURA ${ }^{2}$ \\ ${ }^{1}$ Masuda Red Cross Hospital, Masuda 698-8501; ${ }^{2}$ Department of Medical Education and Research, \\ Faculty of Medicine, Shimane University, Izumo 693-8501, Japan
}

Received April 23, 2015; Accepted May 25, 2015

DOI: $10.3892 /$ ijo.2015.3028

\begin{abstract}
Although all-trans retinoic acid (ATRA) is a standard and effective drug used for differentiation therapy in acute promyelocytic leukemia, ATRA-resistant leukemia cells ultimately emerge during this treatment. Therefore, the development of new drugs or effective combination therapy is urgently needed. We demonstrate that the combined treatment of vitamin $\mathrm{K} 2$ and cotylenin A synergistically induced monocytic differentiation in HL-60 cells. This combined treatment also synergistically induced NBT-reducing activity and non-specific esterase-positive cells as well as morphological changes to monocyte/macrophage-like cells. Vitamin $\mathrm{K} 2$ and cotylenin A cooperatively inhibited the proliferation of HL-60 cells in short-term and long-term cultures. This treatment also induced growth arrest at the G1 phase. Although $5 \mu \mathrm{g} / \mathrm{ml}$ cotylenin $\mathrm{A}$ or $5 \mu \mathrm{M}$ vitamin $\mathrm{K} 2$ alone reduced $c-M Y C$ gene expression in HL-60 cells to approximately $45 \%$ or $80 \%$ that of control cells, respectively, the combined treatment almost completely suppressed $c-M Y C$ gene expression. We also demonstrated that the combined treatment of vitamin $\mathrm{K} 2$ and cotylenin A synergistically induced the expression of cyclin G2, which had a positive effect on the promotion and maintenance of cell cycle arrest. These results suggest that the combination of vitamin $\mathrm{K} 2$ and cotylenin A has therapeutic value in the treatment of acute myeloid leukemia.
\end{abstract}

\section{Introduction}

Acute myeloid leukemia (AML) is the most common type of leukemia in adults, and occurs in approximately one-third of

Correspondence to: Professor Takashi Kasukabe, Department of Medical Education and Research, Faculty of Medicine, Shimane University, Izumo 693-8501, Japan

E-mail: kasukabe@med.shimane-u.ac.jp

Key words: vitamin K2, cotylenin A, differentiation, growth arrest, acute myeloid leukemia cells, $c-M Y C$, cyclin G2 newly diagnosed patients, and remains one of the most difficult hematological malignancies to treat (the 5-year overall survival rate is $20-30 \%$ for adult primary AML) $(1,2)$. AML is characterized by the proliferation of clonal precursor myeloid cells with arrested differentiation (3). In contrast to the poor prognosis of most patients with AML, the use of differentiation therapy with all-trans-retinoic acid (ATRA) for acute promyelocytic leukemia (APL), a distinct type of AML, has revolutionized therapy for this disease by converting it from fatal to curable (4). However, ATRA is not effective in other AMLs. Furthermore, many APL patients treated with ATRA fail to respond or invariably relapse. Therefore, alternative or combination therapies are needed to improve the prognosis and survival of patients.

Cotylenin A (CN-A), which is a fucicoccan-diterpene glycoside with a complex sugar moiety, was originally isolated as a plant growth regulator and has been shown to affect several physiological processes in higher plants (5). We previously reported that $\mathrm{CN}-\mathrm{A}$ exhibited potent differentiation-inducing activity in several human and murine myeloid leukemia cell lines and in leukemia cells that were freshly isolated from patients with AML (6-9). Furthermore, the administration of $\mathrm{CN}-\mathrm{A}$ significantly prolonged the survival of mice with severe combined immunodeficiency that had been inoculated with the APL cells of the NB-4 cell line (10).

Previous studies reported that vitamin K2 (VK2) effectively induced apoptosis in various types of primary cultured leukemia cells and leukemia cell lines in vitro (11-13) as well as in solid tumor cells (14-16). On the other hand, in contrast to the induction of apoptosis in leukemia cells, VK2 has been shown to exhibit differentiation-inducing activity in AML cell lines, such as HL-60 and U937, in vitro (17-19). Sada et al found that VK2 also had differentiation-promoting effects on myeloid lineage progenitors (20).

Since $c-M Y C$ is aberrantly expressed in a wide variety of human solid tumors (21) as well as in leukemia (22), it is an attractive target for cancer therapy. The downregulation of $c-M Y C$ is known to play a crucial role in ATRA-induced growth arrest and myeloid differentiation of AML (23-27). In addition, previous findings, including ours, indicated that the expression of cyclin G2 was significantly upregulated during 
cell cycle arrest responses to diverse growth-inhibitory signals and strongly repressed by mitogens, suggesting the positive role of cyclin G2 in the promotion or maintenance of cell cycle arrest (28-30). In order to identify useful new differentiation inducers and effective combination treatments for various types of AML and APL, we searched for substances capable of inducing cell differentiation and the expression of cyclin $\mathrm{G} 2$ as well as strongly suppressing the expression of $c-M Y C$ in HL-60 cells. In the present study, we demonstrated that the combined treatment of VK2 and CN-A synergistically induced monocytic differentiation in HL-60 cells and cooperatively inhibited cell proliferation showing G1 arrest. Furthermore, we showed that the combined treatment of VK2 and CN-A efficiently suppressed the expression of $c-M Y C$ and cooperatively induced the expression of cyclin G2.

\section{Materials and methods}

Reagents. VK2, nitroblue tetrazolium (NBT), all-trans retinoic acid (ATRA), 1 $\alpha, 25$-dihydroxyvitamin D3 (VD3), and 12- $O$-tetradecanoylphorbol-13-acetate (TPA) were purchased from Sigma-Aldrich Inc. (St. Louis, MO, USA). CN-A was purified from a stock ethyl acetate extract obtained from the culture filtrate of Cladosporium fungus sp. 501-7 W by flash chromatography on a silica gel with $>99 \%$ purity (5).

Cells and cell culture. Human AML HL-60 cells were cultured in RPMI-1640 medium (Sigma-Aldrich Inc.) supplemented with $10 \%$ heat-inactivated fetal bovine serum and $80 \mu \mathrm{g} / \mathrm{ml}$ gentamicin sulfate (MSD K.K, Tokyo, Japan) at $37^{\circ} \mathrm{C}$ in a humidified atmosphere of $5 \% \mathrm{CO}_{2}$ in air.

Assay of cell growth. Cells were plated in multidishes (Falcon, Corning Inc., Corning, NY, USA) at a density of $2.5 \times 10^{4}$ cells $/ \mathrm{ml}$ and incubated with or without the test compounds. Cell numbers were counted with a model Z1 Coulter Counter (Beckman Coulter Inc., Miami, FL, USA).

$N B T$ reduction assay. The reduction of NBT was assayed colorimetrically as previously described (31). Briefly, cells were incubated in $1 \mathrm{ml}$ of serum-free medium containing $1 \mathrm{mg} / \mathrm{ml} \mathrm{NBT}$ and $100 \mathrm{ng} / \mathrm{ml} \mathrm{TPA}$ at $37^{\circ} \mathrm{C}$ for $60 \mathrm{~min}$. The reaction was stopped by adding $\mathrm{HCl}$. Formazan solution at $560 \mathrm{~nm}$ was measured in a spectrophotometer (DU730, Beckman Coulter Inc.).

Assessment of monocytic differentiation. In order to assess monocytic differentiation, non-specific esterase staining was performed using an Esterase Staining kit (Muto Chemical Co., Tokyo, Japan).

Assessment of morphological differentiation. Morphological changes were examined in cell smears using light microscopy of cytospin preparations stained with May-Grunwald-Giemsa solution (Merck, Darmstadt, Germany).

Cell cycle analysis. Cells were plated in $60-\mathrm{mm}$ plastic dishes at a density of $1 \times 10^{5}$ cells $/ \mathrm{ml}$ and incubated with VK2 in the absence or presence of CN-A. After $96 \mathrm{~h}$, the cells were washed with phosphate-buffered saline (PBS) and
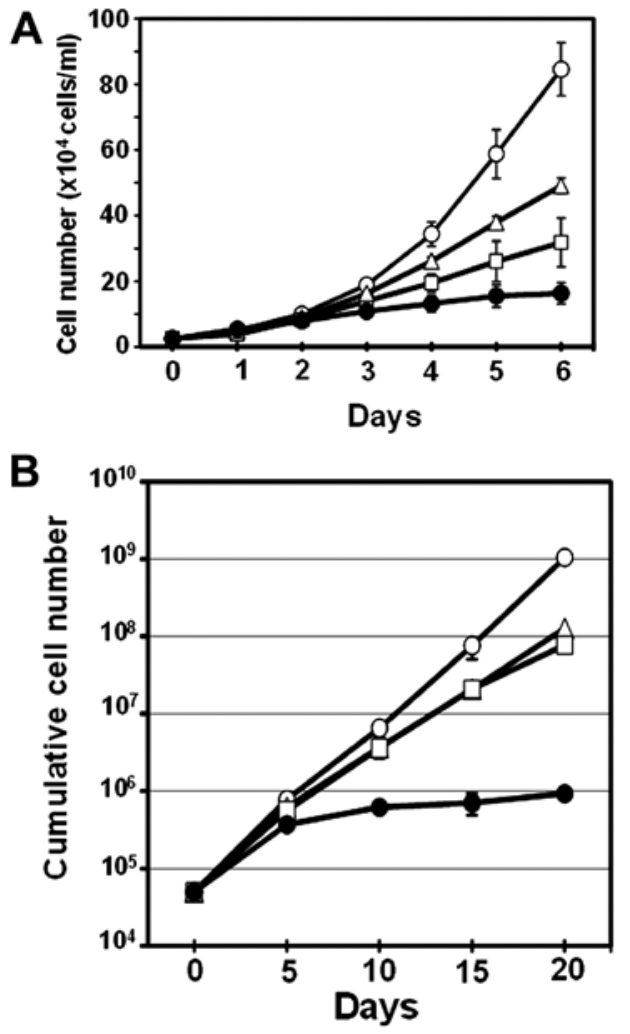

Figure 1. Effects of the combined treatment of vitamin K2 (VK2) and cotylenin A (CN-A) on cell proliferation in HL-60 cells. (A) HL-60 cells $\left(2.5 \times 10^{4}\right.$ cells $\left./ \mathrm{ml}\right)$ were cultured without (open circle) or with $5 \mu \mathrm{M} \mathrm{VK} 2$ (open square), $5 \mu \mathrm{g} / \mathrm{ml} \mathrm{CN}$-A (open triangle), or $5 \mu \mathrm{M}$ VK2 plus $5 \mu \mathrm{g} / \mathrm{ml}$ $\mathrm{CN}-\mathrm{A}$ (closed circle) for the indicated number of days. (B) HL-60 cells $\left(5 \times 10^{4}\right.$ cells $\left./ \mathrm{ml}\right)$ were cultured without (open circle) or with $10 \mu \mathrm{M}$ VK2 (open square), $5 \mu \mathrm{g} / \mathrm{ml} \mathrm{CN-A} \mathrm{(open} \mathrm{triangle),} \mathrm{or} 10 \mu \mathrm{M} \mathrm{VK} 2$ plus $5 \mu \mathrm{g} / \mathrm{ml}$ $\mathrm{CN}-\mathrm{A}$ (closed circle) for the indicated number of days. The culture medium was replaced by fresh medium once every 5 days. Cell density was maintained at $5-90 \times 10^{4}$ cells $/ \mathrm{ml}$. Values are expressed as the mean $\pm \mathrm{SD}$ of three determinations.

fixed gently in $100 \%$ ethanol at $4^{\circ} \mathrm{C}$ for $30 \mathrm{~min}$. Cells were suspended in propidium iodide (PI)-RNase solution, which contained $50 \mu \mathrm{g} / \mathrm{ml}$ PI (MBL Co. Ltd., Nagoya, Japan) and $0.1 \mathrm{mg} / \mathrm{ml}$ RNase (Sigma-Aldrich Inc.) in PBS for $30 \mathrm{~min}$ at room temperature. The cell cycle analysis was performed by flow cytometry (BD FACSCalibur, Becton Dickinson, East Rutherford, NJ, USA).

$R N A$ extraction and determination of $m R N A$ levels by reverse transcriptase (RT)-quantitative polymerase chain reaction $(q P C R)$. RNA was extracted using an RNeasy Plus Mini kit (Qiagen, Valencia, CA, USA) according to the manufacturer's instructions. Total RNA $(1 \mu \mathrm{g})$ from leukemia cells was reverse transcribed with the ReverTra Ace qPCR RT kit (Toyobo Co. Ltd., Osaka, Japan). qPCR using the SYBER Green method was carried out with the Thunderbird SYBER qPCR Mix (Toyobo Co.) on a Thermal Cycler Dice Real-time PCR instrument (Takara Bio, Shiga, Japan) according to the manufacturer's instructions. Real-time PCR results were calculated according to the following protocol: Relative expression level $=2^{-\Delta C t}$, where $\Delta \mathrm{Ct}=\mathrm{Ct}$ (gene of interest) - $\mathrm{Ct}$ (housekeeping gene). The $c-M Y C$ primers used for qPCR were: forward, 5'-TTCGGGT AGTGGAAAACCAG-3' and reverse, 5'-CAGCAGCTCGAA 


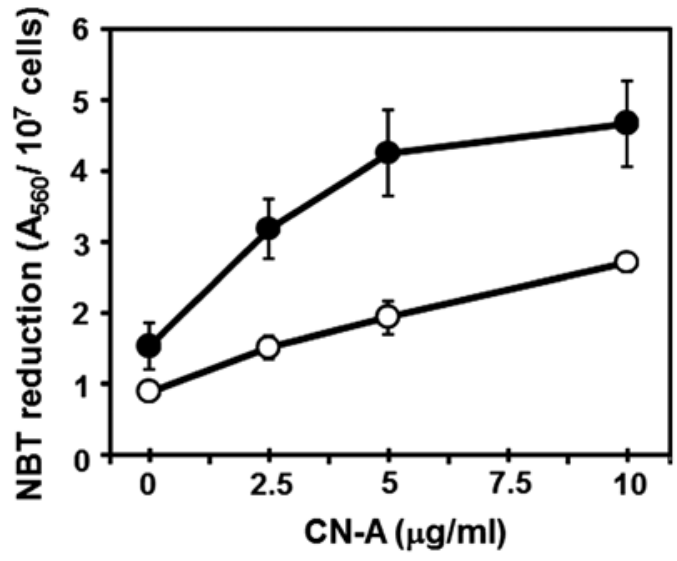

Figure 2. Induction of NBT reduction in HL- 60 cells by the treatment with $\mathrm{CN}-\mathrm{A}$ and VK2. HL-60 cells $\left(2.5 \times 10^{4}\right.$ cells $\left./ \mathrm{ml}\right)$ were cultured with $\mathrm{CN}-\mathrm{A}$ in the presence (closed circle) and absence (open circle) of $10 \mu \mathrm{M} \mathrm{VK} 2$ for 6 days. NBT-reducing activities were determined. Values are expressed as the mean \pm SD of three determinations.

TTTCTTCC-3'. The GAPDH primers used for qPCR were: forward, 5'-GACGCTGGGGCTGGCATTG-3' and reverse, 5'-GCTGGTGGTCCAGGGGTC-3' (32). The cyclin G2 primers used for qPCR were: forward, 5'-ATCGTTTCAAG GCGCACAG-3' and reverse, 5'-CAACCCCCCTCAGGTA TCG-3' (33). The P21/CIP1 primers used for qPCR were: forward, 5'-CGATGCCAACCTCCTCAACGA-3' and reverse, 5'-TCGCAGACCTCCAGCATCCA-3 (34).

\section{Results}

Effects of the combined treatment of vitamin $K 2$ (VK2) and cotylenin A (CN-A) on the cell proliferation of $H L-60$ cells. HL-60 cells $\left(2.5 \times 10^{4}\right.$ cells $\left./ \mathrm{ml}\right)$ were cultured without or with VK2, CN-A, or VK2 plus CN-A for 6 days. Fig. 1A shows the time course of the combined effects of VK2 and CN-A on cell growth. The growth of HL-60 cells was moderately inhibited by VK2 $(5 \mu \mathrm{M})$ or CN-A $(5 \mu \mathrm{g} / \mathrm{ml})$ alone, but was still observed until at least 6 days; however, no significant changes were observed in the cell number after 4 days of the treatment with the combination of both VK2 and CN-A (Fig. 1A). We also examined the long-term effects of the combined treatment of VK2 and CN-A on the proliferation of HL-60 cells. HL-60 cells $\left(5 \times 10^{4}\right.$ cells $\left./ \mathrm{ml}\right)$ were cultured without or with $10 \mu \mathrm{M}$ $\mathrm{VK} 2,5 \mu \mathrm{g} / \mathrm{ml} \mathrm{CN}-\mathrm{A}$, or $10 \mu \mathrm{M}$ VK2 plus $5 \mu \mathrm{g} / \mathrm{ml} \mathrm{CN}-\mathrm{A}$ for 20 days (Fig. 1B). The culture medium was replaced by fresh medium once every 5 days. Although the growth rate of VK2- or CN-A-treated cells was significantly lower than that of control cells under these culture conditions, the cell number markedly increased (100-fold between days 5 and 20). On the other hand, cell growth was greatly inhibited by the combined treatment of VK2 and CN-A, and the cell number was almost the same as that at day 5 (Fig. 1B).

VK2 and CN-A synergistically induced monocytic differentiation in HL-60 cells. We examined the combined effects of VK2 and CN-A on the induction of differentiation of HL-60 cells because VK2 or CN-A alone are inducers of differentiation in HL-60 cells $(6,7,17,18)$. HL-60 cells $\left(2.5 \times 10^{4}\right.$ cells $\left./ \mathrm{ml}\right)$
A a
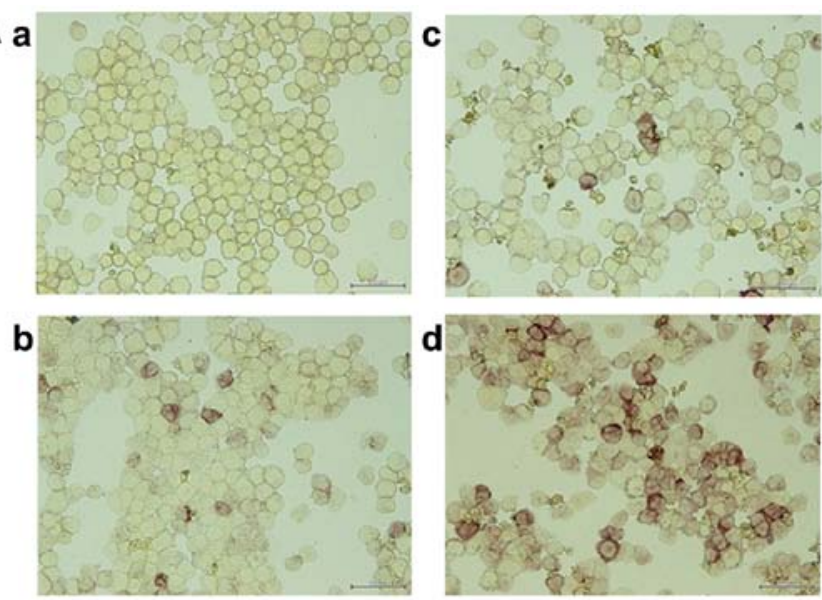

B

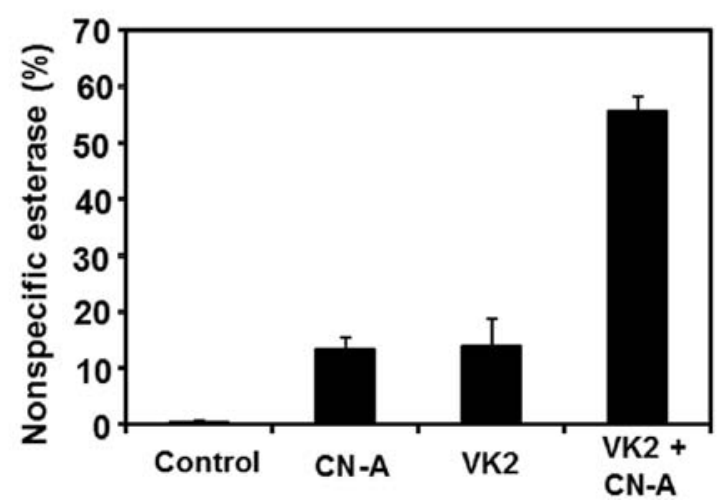

Figure 3. Induction of non-specific esterase in HL-60 cells by the treatment with CN-A and VK2. (A) HL-60 cells $\left(2.5 \times 10^{4}\right.$ cells $\left./ \mathrm{ml}\right)$ were cultured without (a) or with $10 \mu \mathrm{g} / \mathrm{ml} \mathrm{CN-A} \mathrm{(b),} 10 \mu \mathrm{M} \mathrm{VK} 2$ (c), or $10 \mu \mathrm{M} \mathrm{VK} 2$ plus $10 \mu \mathrm{g} / \mathrm{ml}$ $\mathrm{CN}-\mathrm{A}$ (d) for 5 days. The results are representative of 3 independent experiments. (B) Non-specific esterase-positive cells were counted by microscopy. Data are representative of the mean \pm SD of three determinations.

were cultured with $\mathrm{CN}-\mathrm{A}$ in the presence or absence of $\mathrm{VK} 2$ for 6 days. $\mathrm{CN}-\mathrm{A}$ and $10 \mu \mathrm{M} \mathrm{VK} 2$ synergistically induced the reduction of NBT (one of the typical myelo/monocytic differentiation markers of human leukemia cells) (Fig. 2). We then determined whether the induction of differentiation induced with VK2 plus CN-A was a granulocytic or monocytic lineage. HL-60 cells $\left(2.5 \times 10^{4}\right.$ cells $\left./ \mathrm{ml}\right)$ were cultured without or with $10 \mu \mathrm{g} / \mathrm{ml} \mathrm{CN}-\mathrm{A}, 10 \mu \mathrm{M}$ VK2 , or $10 \mu \mathrm{M} \mathrm{VK} 2$ plus $10 \mu \mathrm{g} / \mathrm{ml}$ $\mathrm{CN}$-A for 5 days (Fig. 3A). Nonspecific esterase-positive cells were counted under a microscope (Fig. 3B). Cells treated with CN-A plus VK2 synergistically became positive for nonspecific esterase (Fig. 3A-d and B), whereas those treated with $\mathrm{CN}-\mathrm{A}$ or VK2 alone became weakly positive (Fig. 3A-b, A-c and $\mathrm{B}$ ). The combined treatment of $\mathrm{VK} 2$ and $\mathrm{CN}-\mathrm{A}$ also induced the marked morphological differentiation of HL-60 cells (Fig. 4D), whereas VK2 or CN-A alone induced the intermediate stage of differentiation (Fig. 4B and C). These results indicated that the treatment of HL-60 cells with VK2 and $\mathrm{CN}-\mathrm{A}$ effectively induced monocytic differentiation.

Induction of G1 arrest in HL-60 cells with VK2 plus $C N-A$. In order to more clearly understand the combined effects of VK2 and CN-A on cell growth, we exposed HL-60 cells $\left(1 \times 10^{5}\right.$ cells $\left./ \mathrm{ml}\right)$ to $10 \mu \mathrm{M} \mathrm{VK} 2$ plus $10 \mu \mathrm{g} / \mathrm{ml} \mathrm{CN}-\mathrm{A}$, and then measured changes in cell cycle distribution after 4 days 

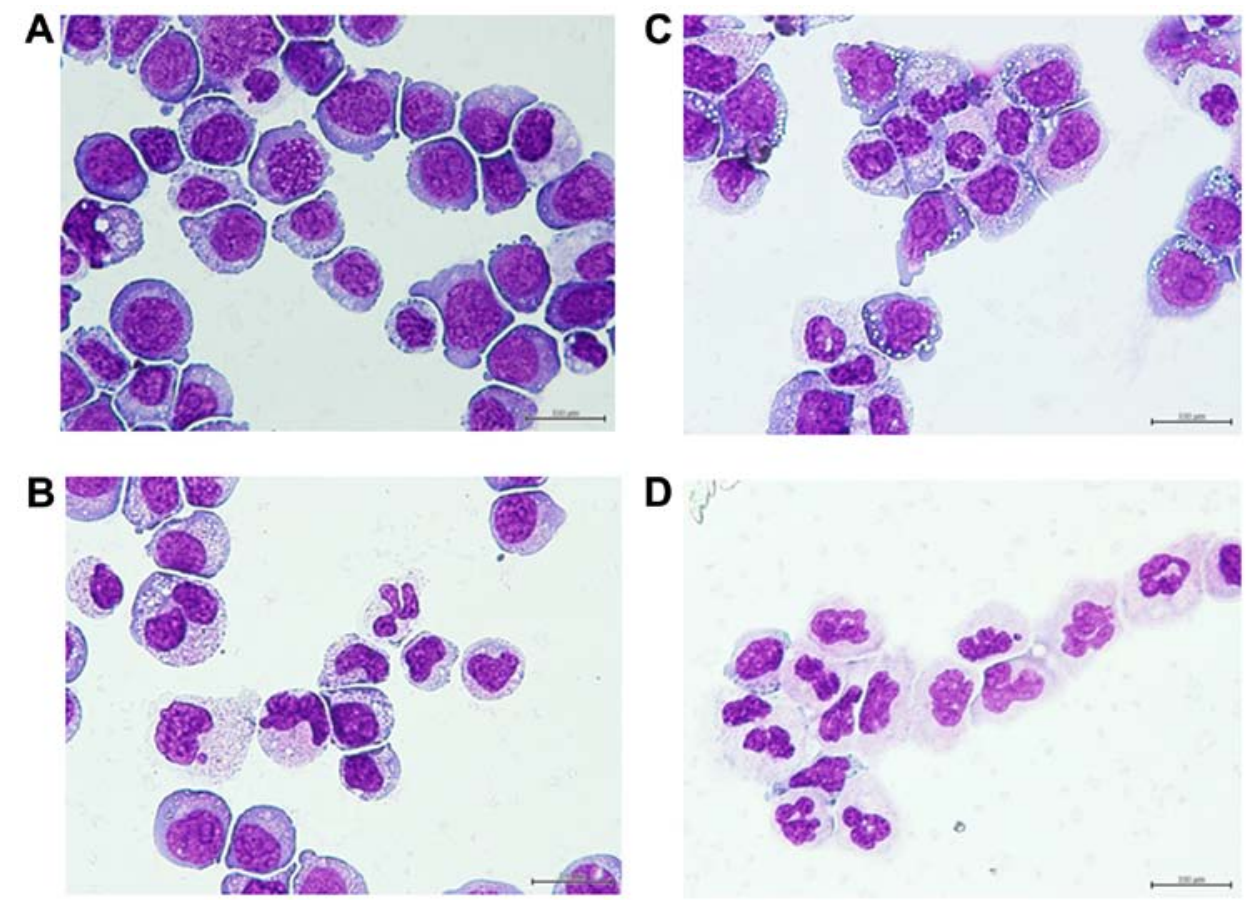

Figure 4. Induction of morphological differentiation in HL-60 cells by the treatment with CN-A and VK2. HL-60 cells $\left(2.5 \times 10^{4}\right.$ cells $\left./ \mathrm{ml}\right)$ were cultured without (A) or with $5 \mu \mathrm{g} / \mathrm{ml} \mathrm{CN}-\mathrm{A}$ (B), $5 \mu \mathrm{M} \mathrm{VK} 2$ (C), or $5 \mu \mathrm{M} \mathrm{VK} 2$ plus $5 \mu \mathrm{g} / \mathrm{ml} \mathrm{CN}-\mathrm{A}$ (D) for 6 days. The results are representative of 3 independent experiments.
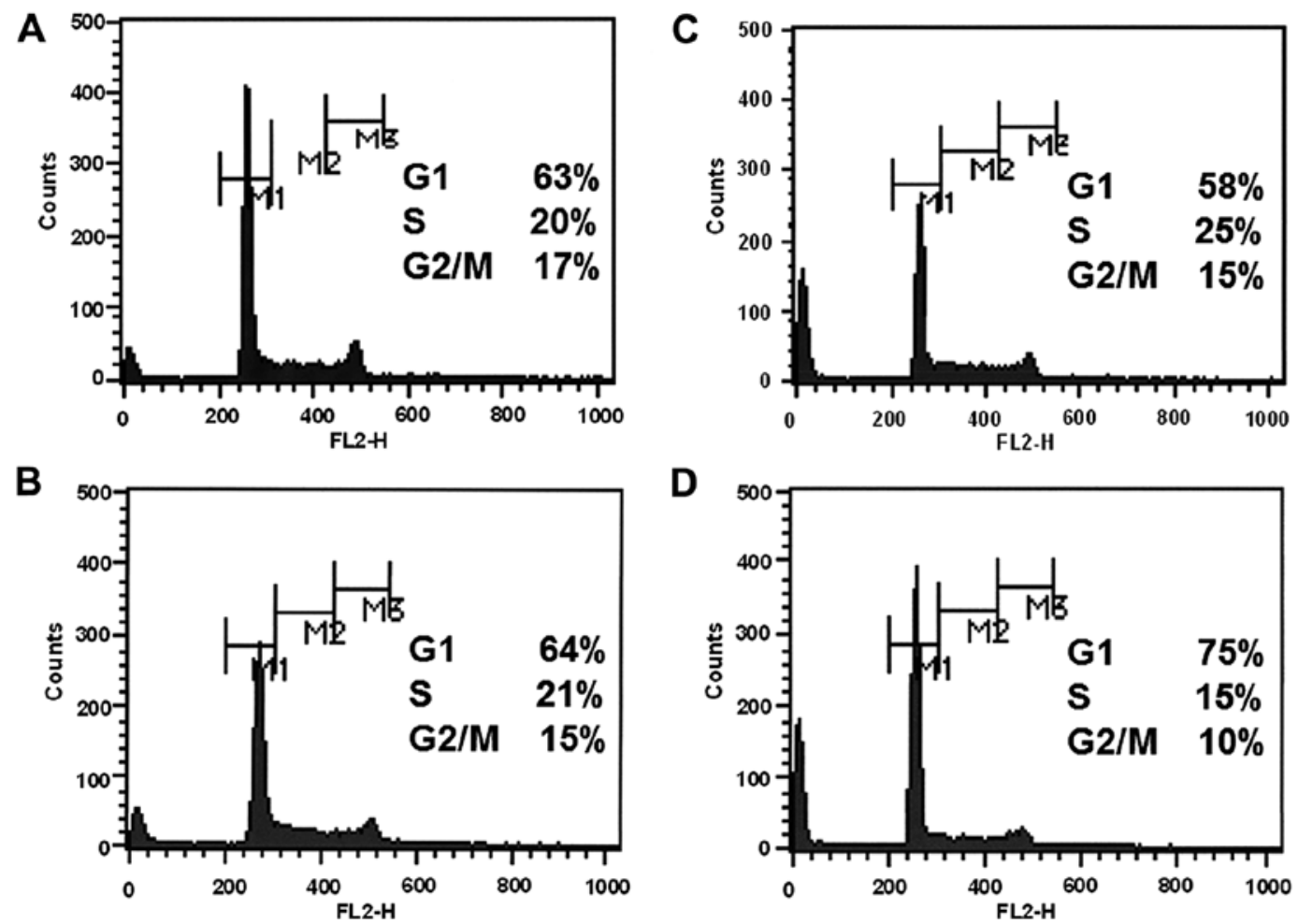

Figure 5. Induction of G1 arrest in HL-60 cells with VK2 plus CN-A. HL-60 cells (1x10 cells/ml) were cultured without (A) or with $10 \mu \mathrm{g} / \mathrm{ml} \mathrm{CN-A} \mathrm{(B),} 10 \mu \mathrm{M}$ VK2 (C), or $10 \mu \mathrm{M}$ VK2 plus $10 \mu \mathrm{g} / \mathrm{ml} \mathrm{CN-A} \mathrm{(D)} \mathrm{for} 4$ days and a cell cycle analysis was performed using flow cytometry. Ten thousand cells were scored in each cytoplasmic profile. The results are representative of 3 independent experiments.

(Fig. 5). Under these culture conditions, VK2 or CN-A alone did not markedly affect the cell cycle (Fig. 5B and C). On the other hand, the percentage of cells in the G1 phase was significantly increased from $63 \%$ to $75 \%$ (Fig. 5A and D). The percentages of cells in the S phase and G2/M phase were inversely decreased in response to the combined treatment of VK2 and CN-A (Fig. 5A and D).

Combined treatment of $V K 2$ and $C N-A$ synergistically inhibited c-MYC gene expression in HL-60 cells. Previous studies 

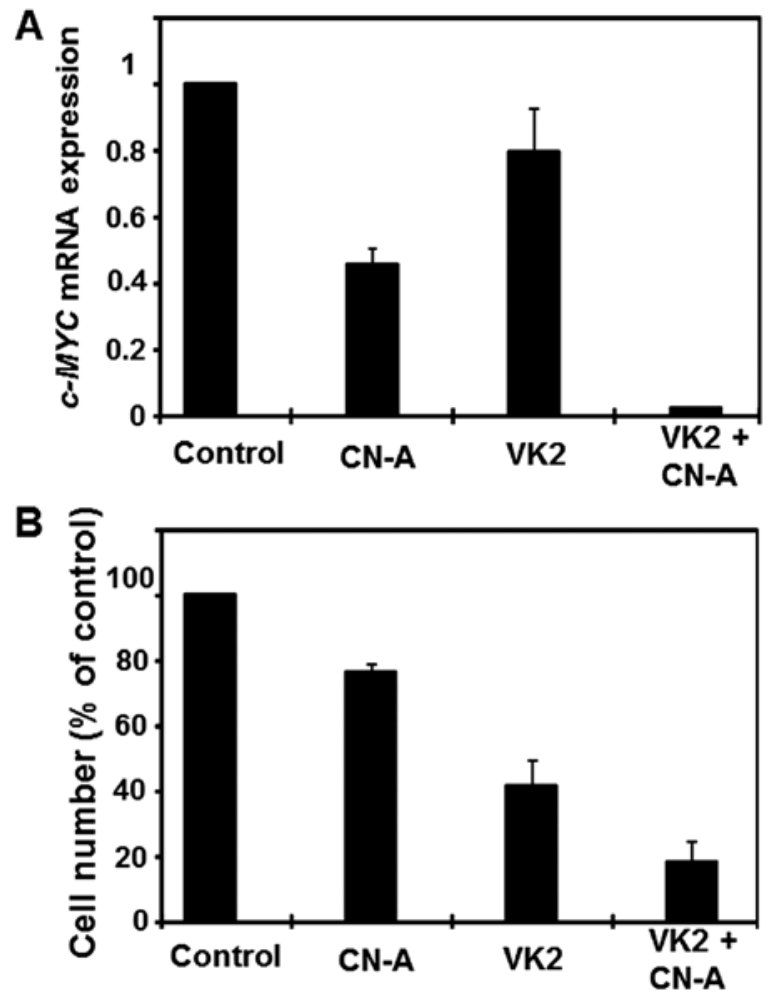

Figure 6. The combined treatment of CN-A and VK2 synergistically inhibited $c-M Y C$ gene expression in HL-60 cells. HL-60 cells $\left(2.5 \times 10^{4}\right.$ cells $\left./ \mathrm{ml}\right)$ were cultured without or with $5 \mu \mathrm{g} / \mathrm{ml} \mathrm{CN}-\mathrm{A}, 5 \mu \mathrm{M}$ VK2 , or $5 \mu \mathrm{M} \mathrm{VK} 2$ plus $5 \mu \mathrm{g} / \mathrm{ml} \mathrm{CN-A}$ for 6 days. c-MYC gene expression (A) was examined by RT-qPCR and the number of cells (B) was measured using a cell counter. Data are representative of the mean $\pm \mathrm{SD}$ of three determinations.

reported that the induction of differentiation and growth arrest in HL-60 cells was associated with the suppression of $c-M Y C$ gene expression (23-27); therefore, we investigated whether the combined treatment of CN-A and VK2 synergistically inhibited $c-M Y C$ gene expression in HL-60 cells. HL-60 cells $\left(2.5 \times 10^{4}\right.$ cells $\left./ \mathrm{ml}\right)$ were cultured without or with VK2 plus CN-A for 6 days. Although $5 \mu \mathrm{g} / \mathrm{ml} \mathrm{CN-A}$ or $5 \mu \mathrm{M}$ VK2 alone inhibited $c-M Y C$ gene expression in HL-60 cells to approximately 45 or $80 \%$ that of control cells, respectively, the combined treatment almost completely suppressed $c-M Y C$ gene expression ( $>95 \%$ inhibition) (Fig. 6A). This synergistic inhibition of $c-M Y C$ gene expression in HL-60 cells was also observed when HL-60 cells were treated with CN-A and VK2 for 4 days (data not shown). As described above, the combined treatment of CN-A and VK2 more strongly inhibited cell growth than that of CN-A or VK2 alone (Fig. 6B) and clearly induced monocytic differentiation (Fig. 4).

Combined treatment of $V K 2$ and $C N-A$ synergistically induced cyclin $G 2$ gene expression in HL-60 cells. Previous findings, including ours, indicated that the expression of cyclin G2 was significantly upregulated during cell cycle arrest responses to diverse growth-inhibitory signals and strongly repressed by mitogens, suggesting a positive role for cyclin G2 in the promotion or maintenance of cell cycle arrest (28-30). Therefore, we determined whether the differentiation of HL-60 cells induced with VK2 and CN-A was accompanied by the induction of cyclin $\mathrm{G} 2$ expression. Cyclin
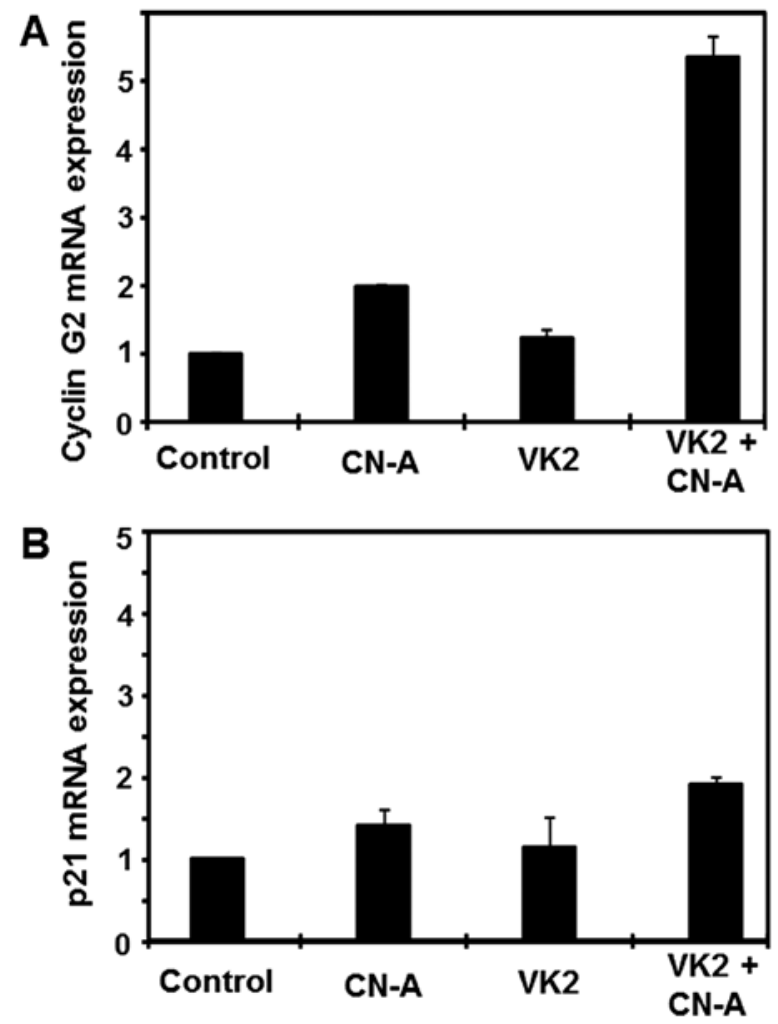

Figure 7. The combined treatment of CN-A and VK2 markedly induced cyclin G2 gene expression in HL-60 cells. HL-60 cells $\left(2.5 \times 10^{4}\right.$ cells $\left./ \mathrm{ml}\right)$ were cultured without or with $5 \mu \mathrm{g} / \mathrm{ml} \mathrm{CN}-\mathrm{A}, 5 \mu \mathrm{M}$ VK2 , or $5 \mu \mathrm{M}$ VK2 plus $5 \mu \mathrm{g} / \mathrm{ml} \mathrm{CN}$-A for 6 days. Cyclin G2 (A) and p21/CIP1 gene expression (B) was examined by RT-qPCR. Data are representative of the mean $\pm \mathrm{SD}$ of three determinations.

G2 gene expression was markedly induced ( $>5$-fold) in VK2 plus CN-A-treated HL-60 cells (Fig. 7A). The expression of cyclin $\mathrm{G} 2$ was approximately 2-fold higher in CN-A-treated HL-60 cells than in control cells, whereas VK2-treated cells showed only a marginal increase (Fig. 7A). Similar results were obtained when HL-60 cells were treated with VK2 plus $\mathrm{CN}-\mathrm{A}$ for 4 days (data not shown).

We also examined the gene expression levels of several cell cycle regulators such as p21/CIP1, p27/KIP1, and cyclin D1. We did not observe the marked induction ( $>2$-fold) of the expression of p21/CIP1 (Fig. 7B), p27/KIP1 (data not shown), or cyclin D1 (data not shown) in VK2-, CN-A-, or VK2 plus CN-A-treated HL-60 cells.

Effects of VK2 on the expression of c-MYC and cyclin $G 2$ in VD3- or ATRA-treated HL-60 cells. We examined the effects of VK2 on cell growth and the expression of $c-M Y C$ and cyclin G2 in HL-60 cells treated with two typical differentiation inducers. VD3 is one of the most potent monocytic differentiation inducers identified to date $(35,36)$. Although VD3 or VK2 alone inhibited cell growth to approximately 65 or $45 \%$ that of control cells and also suppressed the expression of $c-M Y C$ to approximately 50 or $90 \%$ that of control cells, respectively, the combined treatment of VD3 and VK2 inhibited cell growth to approximately $30 \%$ that of control cells and suppressed the expression of $c-M Y C$ to $<10 \%$ that of control cells (Fig. 8A and B). Furthermore, VD3 plus VK2 cooperatively induced 

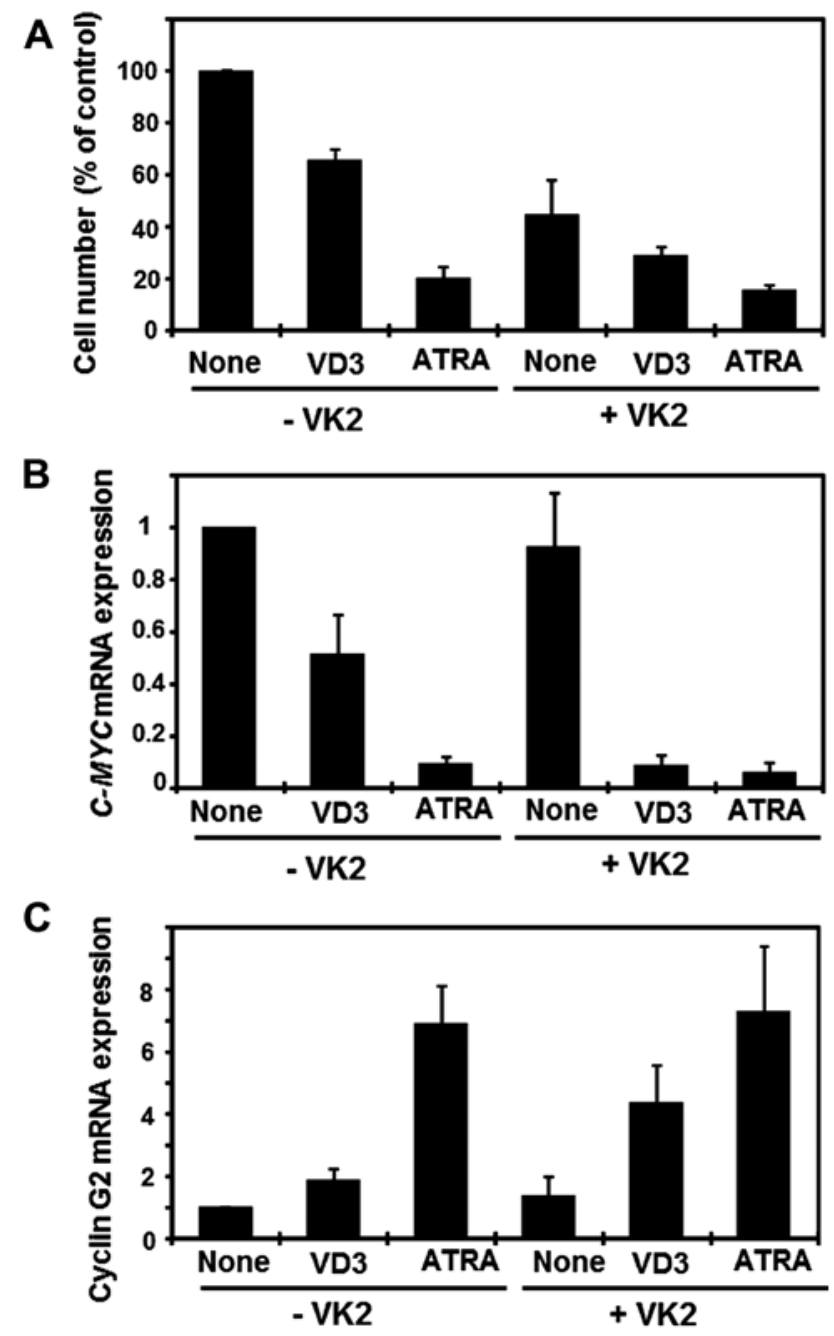

Figure 8. Effects of VK2 on cell growth, $c-M Y C$ expression, and cyclin G2 expression in HL-60 cells in the presence of VD3 or ATRA. HL-60 cells $\left(2.5 \times 10^{4}\right.$ cells $\left./ \mathrm{ml}\right)$ were cultured without or with $100 \mathrm{nM}$ VD3 or $75 \mathrm{nM}$ ATRA in the presence or absence of $5 \mu \mathrm{M}$ VK2 for 6 days. Cell number (A) and the expression of $c-M Y C$ (B) and cyclin G2 (C) were determined. Data are representative of the mean $\pm \mathrm{SD}$ of three determinations.

cyclin G2 gene expression more than that of the additive manner (Fig. 8C). On the other hand, ATRA alone, which is a standard drug used for differentiation therapy in APL, inhibited cell growth to approximately $20 \%$ that of control cells, suppressed $c-M Y C$ expression to $<10 \%$ that of control cells, and markedly induced cyclin G2 gene expression (6.9-fold) (Fig. 8). Under this treatment condition using ATRA, VK2 marginally increased the effects of ATRA on cell growth, $c-M Y C$ expression, and cyclin G2 expression (Fig. 8).

\section{Discussion}

Vitamin Ks (VK) are known to act as co-factor for the $\gamma$-carboxylation of prothrombin and other VK-dependent coagulation factors (37). VK promotes osteogenesis through the $\gamma$-carboxylation of glutamate residues in osteocalcin. $\mathrm{VK} 2$ is a naturally-occurring and the main form of vitamin $\mathrm{K}$ in the tissues. A synthetic VK2 analog has been approved as an anti-osteoporotic medicine by the Ministry of Health, Labor and Welfare in Japan. The safety of the long-term administration of VK2 has been well established (38). Although the exact mechanism has not yet been elucidated in detail, VK2 and their analogs have been shown to inhibit the survival of various cancer cell lines (14-16) and leukemia cells (11-13). Furthermore, previous studies reported that VK2 exhibited some differentiation-inducing activity in AML cell lines in vitro (17-19). Only VK2 alone induced the intermediate stage of differentiation in HL-60 cells in the present study (Fig. 4D) and, even at higher concentrations (>10 $\mu \mathrm{M}), \mathrm{VK} 2$ could not induce mature differentiation, but induced apoptosis (data not shown). As VK2 is a naturally-occurring, safe, and clinically-utilized agent, we searched for substances that could enhance the differentiation-inducing activity of VK2. We found that $\mathrm{CN}-\mathrm{A}$, a differentiation inducer, synergistically induced the differentiation of HL-60 cells along with growth arrest, and markedly suppressed the expression of $c-M Y C$ and induction of cyclin G2 expression. This is the first study to examine the effects of VK2 plus $\mathrm{CN}-\mathrm{A}$ on the induction of differentiation and expression of growth arrest-associated genes such as $c-M Y C$ and cyclin $\mathrm{G} 2$.

The proto-oncogene $c-M Y C$ has been shown to play an important role in cellular metabolism, apoptosis, differentiation, cell cycle progress and tumorigenesis (36-43). The expression of $c-M Y C$ in particular was found to contribute to leukemogenesis and promote the progression of leukemia (43). The downregulation of $c-M Y C$ is critical for the ATRA-induced growth arrest and myeloid differentiation of AML (23-27). The inhibition of $c-M Y C$ was also shown to suppress the proliferation and induce the differentiation of primary AML cells (27). Furthermore, the overexpression of $c-M Y C$ in an APL cell line inversely inhibited ATRA-induced cell differentiation (27). These findings indicate that $c-M Y C$ is an attractive target for differentiation therapy.

In the present study, we found that VK2 markedly enhanced the downregulation of $c-M Y C$ gene expression induced by differentiation inducers, whereas VK2 alone at the doses used weakly suppressed gene expression (Figs. 6A and 8B). The combined treatment of $\mathrm{VK} 2$ and $\mathrm{CN}-\mathrm{A}$ exhibited the most potent suppressive effects on $c-M Y C$ gene expression among the inducers or their combinations tested. This combined treatment reduced the expression of $c-M Y C$ to approximately one fortieth that of control levels (Fig. 6A), and synergistically induced differentiation (Figs. 3 and 4) and growth arrest (Figs. 1 and 5). Although VK2 also effectively enhanced the suppressive effects of $c-M Y C$ expression induced by VD3 (Fig. 8B), VK2 plus VD3 reduced the expression of $c-M Y C$ less than that of VK2 plus CN-A (Figs. 6A and 8B). Furthermore, no derivative of active vitamin D3 has so far been used clinically as an anticancer agent because of the side effect of hypercalcemia (44). These results suggest that the combination of VK2 and CN-A has therapeutic value in the treatment of AML. Furthermore, since we previously found that $\mathrm{CN}-\mathrm{A}$ was also capable of stimulating the functional and morphological differentiation of ATRA-resistant APL cells (10), the combined treatment of VK2 plus CN-A may be useful for differentiation therapy in retinoid-resistant leukemia.

The expression of cyclin G2 was shown to be significantly upregulated during cell cycle arrest responses to diverse growth-inhibitory signals and strongly repressed by mitogens, suggesting the positive role of cyclin G2 in the promotion or 
maintenance of cell cycle arrest (28-30). We previously reported that the combination of differentiation inducers including $\mathrm{CN}-\mathrm{A}$ effectively inhibited the proliferation of several human breast cancer cell lines as well as leukemia cells $(27,43)$. This treatment induced growth arrest in cells at the G1 phase rather than apoptosis and also rapidly and markedly induced cyclin G2 gene expression $(29,45)$.

Cyclin G2 knockdown induced by cyclin G2 small interfering RNA markedly reduced the potency of $\mathrm{CN}-\mathrm{A}$ plus other inducers to induce growth inhibition. Ectopically inducible cyclin G2 expression was shown to potently inhibit the proliferation of breast cancer cells (29). Therefore, for more effective differentiation therapy in AML, it is necessary to find new differentiation inducers or combination therapies that can induce cell differentiation and growth arrest. We have searched for substances that are capable of inducing cell differentiation and the expression of cyclin $\mathrm{G} 2$, and that can also strongly suppress the expression of $c-M Y C$ in HL-60 cells. We showed that the treatment with VK2 plus CN-A induced functional and morphological differentiation as well as growth arrest in HL-60 AML cells. Furthermore, this treatment almost completely suppressed the expression of $c-M Y C$ and markedly induced the expression of cyclin G2. Therefore, our results suggest an attractive combination for effective differentiation therapy in human myeloid leukemia. More detailed studies on the mechanisms underlying this effective combined treatment of $\mathrm{VK} 2$ plus $\mathrm{CN}-\mathrm{A}$ are required.

\section{Acknowledgements}

This study was supported partly by a grant from the Ministry of Education, Culture, Sports, Science and Technology of Japan and by a grant from Shimane University 'SUIGAN' project.

\section{References}

1. Guerrouahen BS, Futami M, Vaklavas C, Kanerva J, Whichard ZL, Nwawka K, Blanchard EG, Lee FY, Robinson LJ, Arceci R, et al: Dasatinib inhibits the growth of molecularly heterogeneous myeloid leukemias. Clin Cancer Res 16: 1149-1158, 2010.

2. Robak T and Wierzbowska A: Current and emerging therapies for acute myeloid leukemia. Clin Ther 31: 2349-2370, 2009.

3. McCulloch EA: Stem cells in normal and leukemic hemopoiesis (Henry Stratton Lecture, 1982). Blood 62: 1-13, 1983.

4. Petrie K, Zelent A and Waxman S: Differentiation therapy of acute myeloid leukemia: Past, present and future. Curr Opin Hematol 16: 84-91, 2009.

5. Sassa T, Tojyo T and Munakata K: Isolation of a new plant growth substance with cytokinin-like activity. Nature 227: 379, 1970.

6. Asahi K, Honma Y, Hazeki K, Sassa T, Kubohara Y, Sakurai A and Takahashi N: Cotylenin A, a plant-growth regulator, induces the differentiation in murine and human myeloid leukemia cells. Biochem Biophys Res Commun 238: 758-763, 1997.

7. Yamamoto-Yamaguchi Y, Yamada K, Ishii Y, Asahi KI, Tomoyasu S and Honma Y: Induction of the monocytic differentiation of myeloid leukaemia cells by cotylenin A, a plant growth regulator. Br J Haematol 112: 697-705, 2001.

8. Yamada K, Honma Y, Asahi KI, Sassa T, Hino KI and Tomoyasu S: Differentiation of human acute myeloid leukaemia cells in primary culture in response to cotylenin A, a plant growth regulator. Br J Haematol 114: 814-821, 2001.

9. Honma Y: Cotylenin A - a plant growth regulator as a differentiation-inducing agent against myeloid leukemia. Leuk Lymphoma 43: 1169-1178, 2002.

10. Honma Y, Ishii Y, Sassa T and Asahi K: Treatment of human promyelocytic leukemia in the SCID mouse model with cotylenin A, an inducer of myelomonocytic differentiation of leukemia cells. Leuk Res 27: 1019-1025, 2003.
11. Yaguchi M, Miyazawa K, Katagiri T, Nishimaki J, Kizaki M, Tohyama K and Toyama K: Vitamin K2 and its derivatives induce apoptosis in leukemia cells and enhance the effect of all-trans retinoic acid. Leukemia 11: 779-787, 1997.

12. Yokoyama T, Miyazawa K, Naito M, Toyotake J, Tauchi T, Itoh M, Yuo A, Hayashi Y, Georgescu MM, Kondo Y, et al: Vitamin K2 induces autophagy and apoptosis simultaneously in leukemia cells. Autophagy 4: 629-640, 2008.

13. Kitagawa J, Hara T, Tsurumi H, Ninomiya S, Ogawa K, Adachi S, Kanemura N, Kasahara S, Shimizu M and Moriwaki H: Synergistic growth inhibition in HL-60 cells by the combination of acyclic retinoid and vitamin K2. J Cancer Res Clin Oncol 137: 779-787, 2011.

14. Mizuta T and Ozaki I: Hepatocellular carcinoma and vitamin K. Vitam Horm 78: 435-442, 2008.

15. Matsumoto K, Okano J, Nagahara T and Murawaki Y: Apoptosis of liver cancer cells by vitamin K2 and enhancement by MEK inhibition. Int J Oncol 29: 1501-1508, 2006.

16. Showalter SL, Wang Z, Costantino CL, Witkiewicz AK, Yeo CJ, Brody JR and Carr BI: Naturally occurring K vitamins inhibit pancreatic cancer cell survival through a caspase-dependent pathway. J Gastroenterol Hepatol 25: 738-744, 2010.

17. Sakai I, Hashimoto S, Yoda M, Hida T, Ohsawa S, Nakajo S and Nakaya K: Novel role of vitamin K2: A potent inducer of differentiation of various human myeloid leukemia cell lines. Biochem Biophys Res Commun 205: 1305-1310, 1994.

18. Miyazawa K, Yaguchi M, Funato K, Gotoh A, Kawanishi Y, Nishizawa Y, Yuo A and Ohyashiki K: Apoptosis/differentiationinducing effects of vitamin K2 on HL-60 cells: Dichotomous nature of vitamin K2 in leukemia cells. Leukemia 15: 1111-1117, 2001.

19. Funato K, Miyazawa K, Yaguchi M, Gotoh A and Ohyashiki K: Combination of 22-oxa-1,25-dihydroxyvitamin $\mathrm{D}(3)$, a vitamin $\mathrm{D}(3)$ derivative, with vitamin $\mathrm{K}(2)$ (VK2) synergistically enhances cell differentiation but suppresses VK2-inducing apoptosis in HL-60 cells. Leukemia 16: 1519-1527, 2002.

20. Sada E, Abe Y, Ohba R, Tachikawa Y, Nagasawa E, Shiratsuchi M and Takayanagi R: Vitamin K2 modulates differentiation and apoptosis of both myeloid and erythroid lineages. Eur J Haematol 85: 538-548, 2010.

21. Field JK and Spandidos DA: The role of ras and myc oncogenes in human solid tumours and their relevance in diagnosis and prognosis (Review). Anticancer Res 10: 1-22, 1990.

22. Delgado MD, Albajar M, Gomez-Casares MT, Batlle A and León J: MYC oncogene in myeloid neoplasias. Clin Transl Oncol 15: 87-94, 2013.

23. Kumakura $S$, Ishikura $H$, Tsumura $H$, Hayashi $H$, Endo $J$ and Tsunematsu T: c-myc protein expression during cell cycle phases in differentiating HL-60 cells. Leuk Lymphoma 14: 171-180, 1994.

24. Kumakura S, Ishikura H, Tsumura H, Iwata Y, Endo J and Kobayashi S: C-Myc and Bcl-2 protein expression during the induction of apoptosis and differentiation in TNF alpha-treated HL-60 cells. Leuk Lymphoma 23: 383-394, 1996.

25. Jiang G, Albihn A, Tang T, Tian Z and Henriksson M: Role of Myc in differentiation and apoptosis in HL60 cells after exposure to arsenic trioxide or all-trans retinoic acid. Leuk Res 32: 297-307, 2008

26. Cheng YC, Lin H, Huang MJ, Chow JM, Lin S and Liu HE: Downregulation of c-Myc is critical for valproic acid-induced growth arrest and myeloid differentiation of acute myeloid leukemia. Leuk Res 31: 1403-1411, 2007.

27. Pan XN, Chen JJ, Wang LX, Xiao RZ, Liu LL, Fang ZG, Liu Q, Long ZJ and Lin DJ: Inhibition of c-Myc overcomes cytotoxic drug resistance in acute myeloid leukemia cells by promoting differentiation. PLoS One 9: e105381, 2014.

28. Horne MC, Donaldson KL, Goolsby GL, Tran D, Mulheisen M, Hell JW and Wahl AF: Cyclin G2 is up-regulated during growth inhibition and B cell antigen receptor-mediated cell cycle arrest. J Biol Chem 272: 12650-12661, 1997.

29. Kasukabe T, Okabe-Kado J and Honma Y: Cotylenin A, a new differentiation inducer, and rapamycin cooperatively inhibit growth of cancer cells through induction of cyclin G2. Cancer Sci 99: 1693-1698, 2008.

30. Zimmermann M, Arachchige-Don AS, Donaldson MS Dallapiazza RF, Cowan CE and Horne MC: Elevated cyclin G2 expression intersects with DNA damage checkpoint signaling and is required for a potent $\mathrm{G} 2 / \mathrm{M}$ checkpoint arrest response to doxorubicin. J Biol Chem 287: 22838-22853, 2012. 
31. Kasukabe T, Honma Y, Hozumi M and Nomura H: Inhibition of proliferation and induction of differentiation of human and mouse myeloid leukemia cells by new ethyleneglycol-type nonphosphorus alkyl ether lipids. Jpn J Cancer Res 81: 807-812, 1990.

32. Marzi I, Cipolleschi MG, D'Amico M, Stivarou T, Rovida E, Vinci MC, Pandolfi S, Dello Sbarba P, Stecca B and Olivotto M: The involvement of a Nanog, Klf4 and $c-M y c$ transcriptional circuitry in the intertwining between neoplastic progression and reprogramming. Cell Cycle 12: 353-364, 2013.

33. Stossi F, Likhite VS, Katzenellenbogen JA and Katzenellenbogen BS: Estrogen-occupied estrogen receptor represses cyclin G2 gene expression and recruits a repressor complex at the cyclin G2 promoter. J Biol Chem 281: 16272-16278, 2006.

34. Liang X-H, Li L-L, Wu G-G, Xie Y-C, Zhang G-X, Chen W, Yang HF, Liu QL, Li WH, He WG, et al: Upregulation of CPE promotes cell proliferation and tumorigenicity in colorectal cancer. BMC Cancer 13: 412, 2013.

35. Tanaka H, Abe E, Miyaura C, Kuribayashi T, Konno K, Nishii Y and Suda T: 1 alpha,25-Dihydroxycholecalciferol and a human myeloid leukaemia cell line (HL-60). Biochem J 204: 713-719, 1982.

36. Kasukabe T, Honma Y, Hozumi M, Suda T and Nishii Y: Control of proliferating potential of myeloid leukemia cells during long-term treatment with vitamin D3 analogues and other differentiation inducers in combination with antileukemic drugs: In vitro and in vivo studies. Cancer Res 47: 567-572, 1987.

37. Vermeer $C$ and Schurgers LJ: A comprehensive review of vitamin $\mathrm{K}$ and vitamin $\mathrm{K}$ antagonists. Hematol Oncol Clin North Am 14 $339-353,2000$
38. Sasaki N, Kusano E, Takahashi H, Ando Y, Yano K, Tsuda E and Asano Y: Vitamin K2 inhibits glucocorticoid-induced bone loss partly by preventing the reduction of osteoprotegerin (OPG). J Bone Miner Metab 23: 41-47, 2005.

39. Masui K, Tanaka K, Akhavan D, Babic I, Gini B, Matsutani T, Iwanami A, Liu F, Villa GR, Gu Y, et al: mTOR complex 2 controls glycolytic metabolism in glioblastoma through FoxO acetylation and upregulation of c-Myc. Cell Metab 18: 726-739, 2013.

40. Sheth A, Escobar-Alvarez S, Gardner J, Ran L, Heaney ML and Scheinberg DA: Inhibition of human mitochondrial peptide deformylase causes apoptosis in c-myc-overexpressing hematopoietic cancers. Cell Death Dis 5: e1152, 2014.

41. Gómez-Casares MT, García-Alegria E, López-Jorge CE, Ferrándiz N, Blanco R, Alvarez S, Vaqué JP, Bretones G, Caraballo JM, Sánchez-Bailón P, et al: MYC antagonizes the differentiation induced by imatinib in chronic myeloid leukemia cells through downregulation of p27(KIP1). Oncogene 32: 2239-2246, 2013.

42. Singh AM and Dalton S: The cell cycle and Myc intersect with mechanisms that regulate pluripotency and reprogramming. Cell Stem Cell 5: 141-149, 2009.

43. Hoffman B, Amanullah A, Shafarenko M and Liebermann DA: The proto-oncogene c-myc in hematopoietic development and leukemogenesis. Oncogene 21: 3414-3421, 2002.

44. DeLuca HF: Evolution of our understanding of vitamin D. Nutr Rev 66 (Suppl 2): S73-S87, 2008.

45. Kasukabe T, Okabe-Kado J, Kato N, Sassa T and Honma Y: Effects of combined treatment with rapamycin and cotylenin A, a novel differentiation-inducing agent, on human breast carcinoma MCF-7 cells and xenografts. Breast Cancer Res 7: R1097-R1110, 2005. 